\title{
Spotlight on fluticasone furoate/vilanterol trifenatate for the once-daily treatment of asthma: design, development and place in therapy
}

This article was published in the following Dove Press journal:

Drug Design, Development and Therapy

14 December 2016

Number of times this article has been viewed

\author{
Timothy E Albertson ${ }^{1-3}$ \\ Samuel W Bullick ${ }^{1,3}$ \\ Michael Schivo' \\ Mark E Sutter ${ }^{2,3}$ \\ 'Division of Pulmonary, Critical Care \\ and Sleep Medicine, Department \\ of Internal Medicine, ${ }^{2}$ Department \\ of Emergency Medicine, School of \\ Medicine, UC Davis, Sacramento, \\ ${ }^{3}$ Department of Medicine, Veterans \\ Administration Northern California \\ Health Care System, Mather, CA, USA
}

Correspondence: Timothy E Albertson Department of Internal Medicine, Division of Pulmonary, Critical Care and Sleep Medicine, School of Medicine, UC Davis, 4I50 V Street, Suite 3100, Sacramento, CA, 958I7, USA Email tealbertson@ucdavis.edu

\begin{abstract}
The use of inhaled corticosteroids (ICSs) plays a key role in the treatment of asthmatic patients, and international guidelines have designated ICSs as an early maintenance therapy in controlling asthma symptoms. When asthmatic patients remain symptomatic on ICSs, one common option is to add a long-acting beta ${ }_{2}$ agonist (LABA) to the maintenance treatment. Fixed combination inhalers that contain both an ICS and a LABA have been popular for both chronic obstructive pulmonary disease (COPD) and asthma. Historically, these inhalers have been dosed twice daily. However, currently, there is a once-daily combination therapy with the ICS fluticasone furoate (FF) and the LABA vilanterol trifenatate (VI) with indications for use in both COPD and asthma. This dry powder inhaler (DPI) comes in two doses of FF (100 or $200 \mu \mathrm{g})$ both combined with VI $(25 \mu \mathrm{g})$. This article reviews the clinical trial data for FF, VI and FF/VI combination inhalers and documents the efficacy and safety of once-daily inhaled maintenance therapy by DPI in asthmatic patients.
\end{abstract}

Keywords: fluticasone furoate/vilanterol trifenatate, asthma, long-acting beta ${ }_{2}$ agonist, inhaled corticosteroid, combined inhaler, persistent asthma, dry powder inhaler

\section{Introduction}

Asthma is an airway disease of inflammation and bronchoconstriction. Genetics and environmental factors combine to produce different asthma phenotypes and various responses to controller medications. The Global Initiative for Asthma (GINA) updated in $2016^{1}$ is an ongoing international effort to provide a unified approach to the diagnosis and treatment of asthma. Table 1 summarizes the GINA general treatment approach to asthma that uses a stepwise function based on the severity of asthma symptoms. The table shows that inhaled corticosteroids (ICSs) play a major role as maintenance or preventative treatments in this stepwise approach to asthma. Table 2 summarizes the currently available and approved handheld inhalers by the US Food and Drug Administration (FDA) and several others not available in the USA. Fluticasone furoate (FF) is a potent corticosteroid that is dosed once daily due to its long half-life when inhaled. It was approved by the FDA as a once-daily ICS for the maintenance treatment of asthma as a dry powder inhaler (DPI) in August 2014 with the brand name Arnuity $^{\mathrm{TM}}$ Ellipta $^{\circledR}$ (GSK, USA). ${ }^{2}$

Controversy exists as to the role of long-acting beta ${ }_{2}$ agonists (LABAs) in the maintenance treatment of moderate to severe asthmatics. Early clinical trials of the LABA salmeterol (SAL) noted a nonstatistically significant increase in all-cause mortality in asthmatic patients treated over 16 weeks when compared to those using 
Table I The 2016 stepwise approach to asthma treatment'

\begin{tabular}{|c|c|c|c|c|c|c|}
\hline $\begin{array}{l}\text { Asthma } \\
\text { step }\end{array}$ & $\begin{array}{l}\text { As-needed } \\
\text { SABA }\end{array}$ & $\begin{array}{l}\text { Low-dose ICS } \\
\text { preferred controller }\end{array}$ & $\begin{array}{l}\text { Medium/high-dose } \\
\text { ICS/LABA }\end{array}$ & $\begin{array}{l}\text { LTRA or } \\
\text { Theo }\end{array}$ & Tiotropium & Alternative \\
\hline Step I & + & + & & & & \\
\hline Step 2 & + & + & & + & & \\
\hline Step 3 & $t^{\mathrm{a}}$ & $t^{\mathrm{b}}$ & $t^{\mathrm{b}}$ & + & & $+^{\mathrm{c}}$ \\
\hline Step 4 & $t^{a}$ & & + & + & $+^{\mathrm{d}}$ & $+^{\mathrm{e}}$ \\
\hline Step 5 & $t^{a}$ & & + & + & $+^{\mathrm{d}}$ & $t^{f}$ \\
\hline
\end{tabular}

Notes: Adapted from GINA 2016.' aMay also include a single low-dose ICS/formoterol as a reliever medication for patients prescribed low-dose BUD/F for maintenance or low-dose BEC/F for those patients using BEC/F for maintenance. 'Preferred step 3 maintenance for children aged 6-II years is medium-dose ICS; adolescent/adults, low-dose

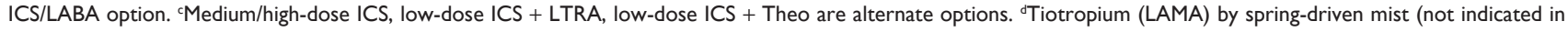
children aged $<12$ years). ${ }^{\mathrm{e}}$ Tiotropium (LAMA) by spring-driven mist, high-dose ICS and LTRA or Theo are alternate options. ${ }^{\mathrm{f}}$ Refer to asthma specialist for add-on treatment options including tiotropium (LAMA), omalizumab, mepolizumab and/or oral corticosteroids.

Abbreviations: BEC/F, beclomethasone dipropionate/formoterol; BUD/F, budesonide/formoterol; GINA, Global Initiative for Asthma; ICS, inhaled corticosteroids; LABA, long-acting beta ${ }_{2}$ agonist; LAMA, long-acting muscarinic antagonist; LTRA, leukotriene receptor antagonist; SABA, short-acting beta ${ }_{2}$ agonist; Theo, theophylline.

the short-acting beta 2 agonist (SABA), albuterol. ${ }^{3}$ A large 2006 clinical trial of 26,355 asthmatics named the Salmeterol Multicenter Asthma Research Trial (SMART) evaluated SAL by metered dose inhaler (MDI) compared to placebo MDI over 28 weeks. ${ }^{4}$ The use of ICS and leukotriene modifiers was equal in both groups (47\% and $11 \%$, respectively). The primary outcome included respiratory-related deaths or life-threatening events, and both were infrequent for the SAL group (50 patients) and placebo group (36 patients). This difference did not reach statistical significance (relative risk $[R R]=1.40,95 \%$ confidence interval $[\mathrm{CI}]=0.91-2.14)$. When secondary outcomes were explored, a small but significant increase in respiratory-related deaths was found in the SAL group (SAL 24 vs placebo 11; $\mathrm{RR}=2.16,95 \%$ $\mathrm{CI}=1.06-4.41$ ) along with specific asthma-related deaths (SAL 13 vs placebo 3; RR =4.37, 95\% CI =1.25-15.4). The secondary outcome imbalances were largely related to the effects on the African-American subpopulation (20 SAL vs 5 placebo; $\mathrm{RR}=4.92,95 \% \mathrm{CI}=1.54-10.90) .{ }^{4}$ This study and a few others resulted in the FDA requiring a "black box" warning for all inhaled LABA agents based on the "risk" of their use in asthma.

Recent studies have called into question if there is an increase in risk to asthmatic patients treated with a combination ICS/LABA inhaler. In 2016, Peters et $\mathrm{l}^{5}$ studied 11,693 adult and adolescent asthmatic patients $\geq 12$ years of age for 26 weeks. They were randomized to the ICS budesonide alone or a fixed-dose combination of budesonide and the LABA formoterol given twice daily by MDI. The budesonide/ formoterol $(\mathrm{BUD} / \mathrm{F})$ combination was found to be noninferior to budesonide alone with 43 patients having a serious asthma-related event in the BUD/F group and 40 patients in the budesonide-alone-treated group (hazard ratio $[\mathrm{HR}]=1.07$, $95 \% \mathrm{CI}=0.70-1.65)$. The risk of an asthma exacerbation was
$16.5 \%$ lower in the BUD/F-treated group compared to the budesonide-alone-treated group $(\mathrm{HR}=0.84,95 \% \mathrm{CI}=0.74$ 0.94). ${ }^{5}$ A similarly designed study in 11,679 asthmatic patients $\geq 12$ years of age treated for 26 weeks also found that the combined fixed-dose fluticasone propionate (FP)/SAL did not have a significantly higher risk of serious asthma-related events and did have a $21 \%$ reduction in severe asthma exacerbations than those treated with fluticasone alone. ${ }^{6}$ Similarly, when a fixed combination inhaler of SAL and FP was compared to inhaled FP alone in 6,208 asthmatic children aged 4-11 years, non-inferiority for serious asthma-related events was seen $(\mathrm{HR}=1.28,95 \% \mathrm{CI}=0.73-2.27){ }^{7}$ These and other data suggest that the combination of an ICS with LABA is a safe and an effective treatment for asthma. Furthermore, the use of both an ICS and a LABA is an integral part of the GINA guidelines (Table 1) for the asthma patient at the step 3-step 5 levels. ${ }^{1}$ Table 2 summarizes the multiple handheld inhalers available in the USA. At this time, LABA monotherapy without the simultaneous use of an ICS is still discouraged and has recently been described as "medical negligence" in children with asthma. ${ }^{8}$

The fixed combination of FF (100 or $200 \mu \mathrm{g})$ combined with the LABA vilanterol trifenatate (VI; $25 \mu \mathrm{g}$ ) was approved in the USA in May 2013 for the maintenance treatment of chronic obstructive pulmonary disease (COPD) as the once-daily DPI Breo Ellipta ${ }^{\circledR}$ (GSK, USA). The same year, the same combination of drugs, doses and delivery system (Relvar Ellipta ${ }^{\circledR}$; GSK, UK) was approved in Japan and the European Union for the treatment of asthma. ${ }^{9}$ Breo Ellipta (FF [100 or $200 \mu \mathrm{g}] / \mathrm{VI}[25 \mu \mathrm{g}]$ ) was approved by the FDA for the maintenance treatment of asthma in April 2015. ${ }^{2}$ This article reviews the data that support the use of the fixed-dose combination of DPI FF with VI as a once-daily asthma maintenance treatment. 


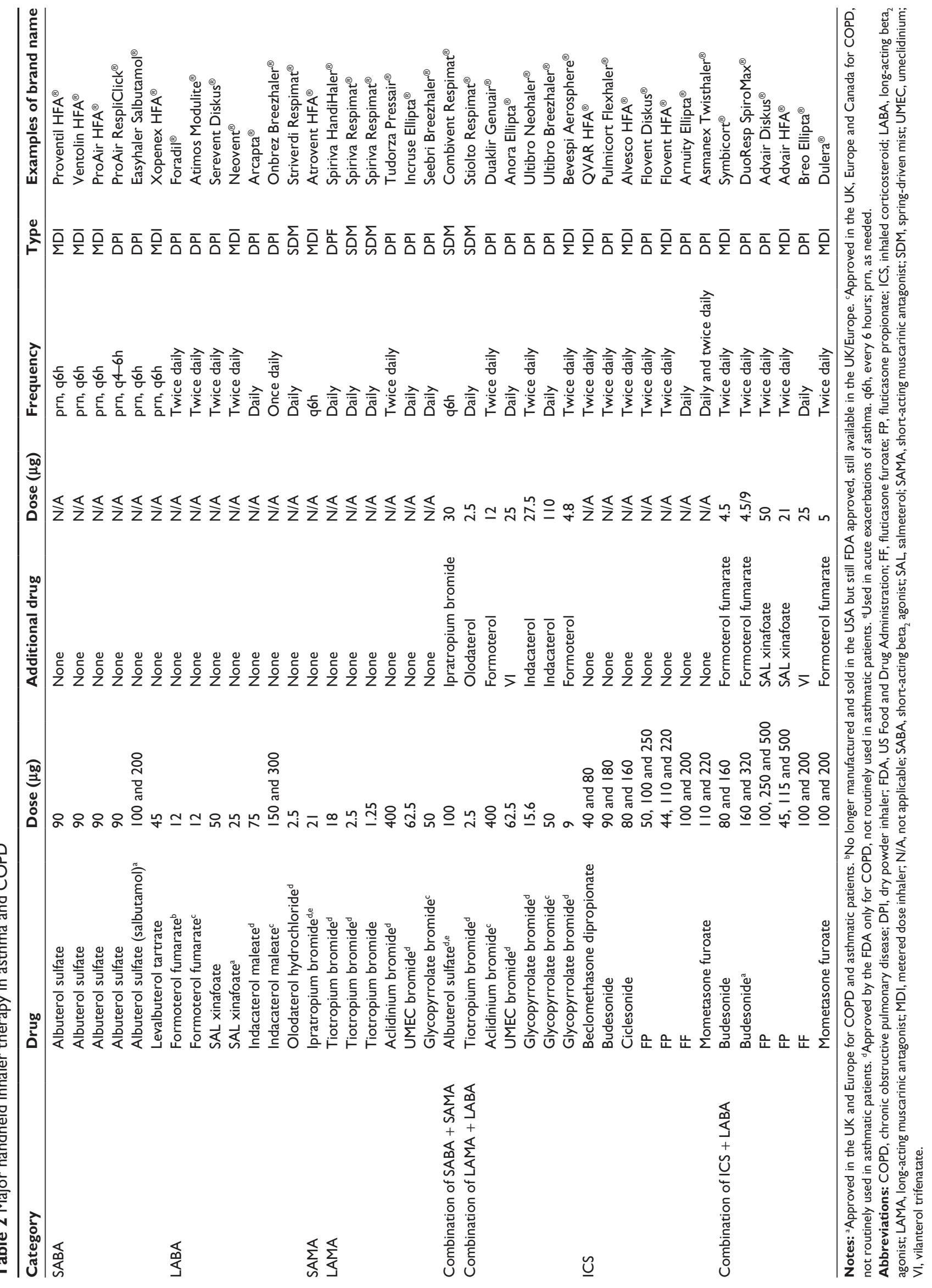




\section{FF in asthma}

The inhaled use of FF in asthma is in part based on its long half-life in the lung that allows once-daily dosing for asthma maintenance therapy..$^{10}$ As given in Table 1, ICS therapy plays a major role in the current GINA guidelines. When as-needed SABAs become inadequate to control asthma symptoms, the use of low-dose ICS should be considered as early as step 1 and used through step 2 into step 3 as medium- to high-dose ICS. The $100 \mu \mathrm{g}$ daily DPI dose of FF is considered low-dose ICS therapy for asthmatics aged 12 years and older. ${ }^{1}$ After the addition of a LABA to low-dose ICS therapy at step 3, higher medium- or high-dose ICS therapy is recommended by the GINA guidelines for asthmatic patients that remain symptomatic. The $200 \mu \mathrm{g}$ daily DPI dose of FF is considered a "high-dose" ICS and can be used for symptomatic step 3-5 asthmatic patients. ${ }^{1}$

Table 3 summarizes the major clinical trials that have examined the use of FF as an ICS maintenance asthma therapy. Efficacy and safety have been verified with oncedaily FF dosing in asthmatic patients in several studies. An 8 -week study of 545 adolescent and adult asthmatic patients demonstrated significant (all $P \leq 0.033$ ) improvements with $\mathrm{FF}$ in pre-dose and placebo-adjusted forced expiratory volume at 1 second $\left(\mathrm{FEV}_{1}\right)$. Once-daily evening-dosed FF $(400 \mu \mathrm{g})$ was also as effective as twice-daily dosing $(200 \mu \mathrm{g})$ of the same total daily FF dose in improving placebo-adjusted $\mathrm{FEV}_{1}(\geq 200 \mathrm{~mL}){ }^{11}$ In this study, the morning-dosed FF $(400 \mu \mathrm{g})$ was found to be less effective than an equal dose of FF $(200 \mu \mathrm{g})$ given twice daily $(202 \mathrm{~mL}$ improvement, 95\% CI $=96-307$ vs $315 \mathrm{~mL}$ improvement, 95\% CI =208$421 \mathrm{~mL}) .{ }^{11}$ A randomized, double-blind, double-dummy and placebo-controlled study further evaluated once-daily FF $(100 \mu \mathrm{g})$ given in the morning compared to the evening over a 2-week trial in asthmatics aged 18-70 years who required an ICS to control symptoms. ${ }^{12}$ Inhaled FF $(100 \mu \mathrm{g})$ daily increased 24-hour weighted mean $\mathrm{FEV}_{1}$ relative to placebo (for AM dosing, $77 \mathrm{~mL}$; 90\% CI $=1-152 \mathrm{~mL}$ and for PM dosing, $105 \mathrm{~mL}$; $90 \% \mathrm{CI}=29-180 \mathrm{~mL})^{13}$ and found that the difference in the increase when FF was given in the morning or evening was negligible (adjusted differences, $28 \mathrm{~mL}$; 90\% CI =-102-45 mL). ${ }^{12}$ A longer 24-week multicenter, double-blind, parallel-group study compared oncedaily evening doses of FF $(100 \mu \mathrm{g})$ to FF $(200 \mu \mathrm{g}) \cdot{ }^{13}$ Both $\mathrm{FF}$ doses improved least-squares mean trough $\mathrm{FEV}_{1}$ from baseline by $208 \mathrm{~mL}$ in the FF $(100 \mu \mathrm{g})$ group and $284 \mathrm{~mL}$ in the FF $(200 \mu \mathrm{g})$ group (treatment difference, $77 \mathrm{~mL}$; $95 \%$ $\mathrm{CI}=-39-192 \mathrm{~mL}) .{ }^{13}$ Similar improvements were seen in rescue- and symptom-free days, morning and evening peak

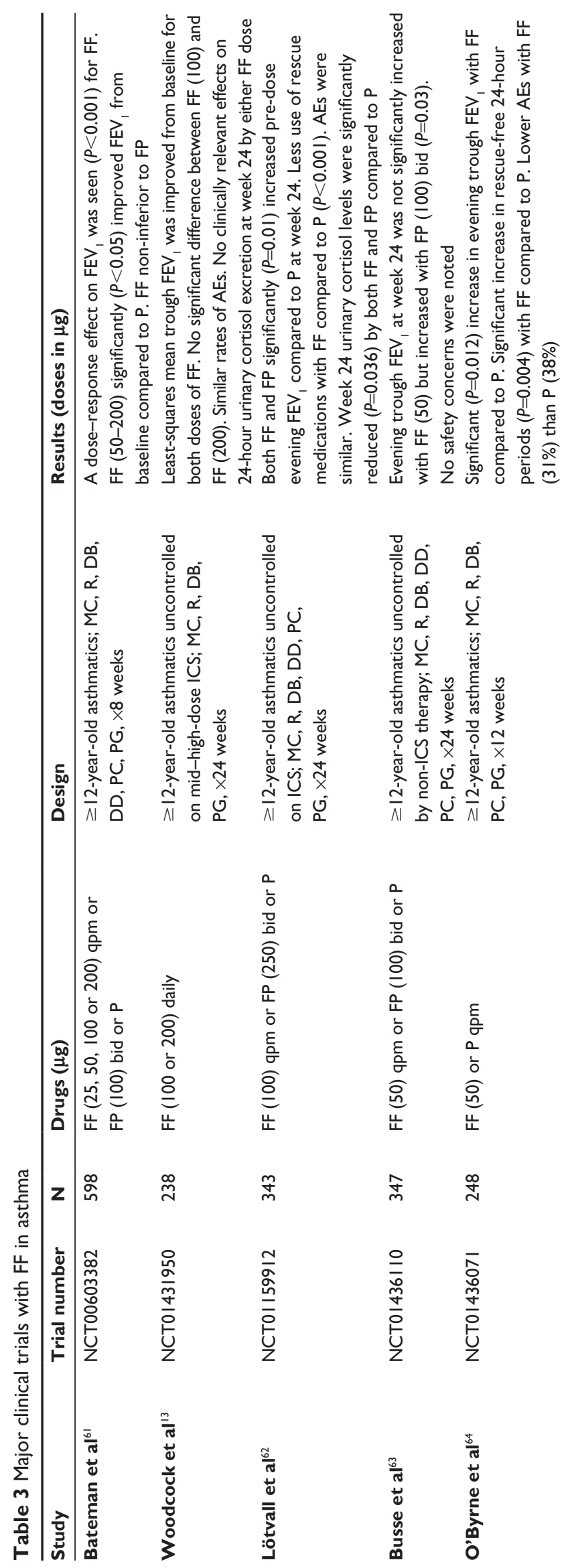




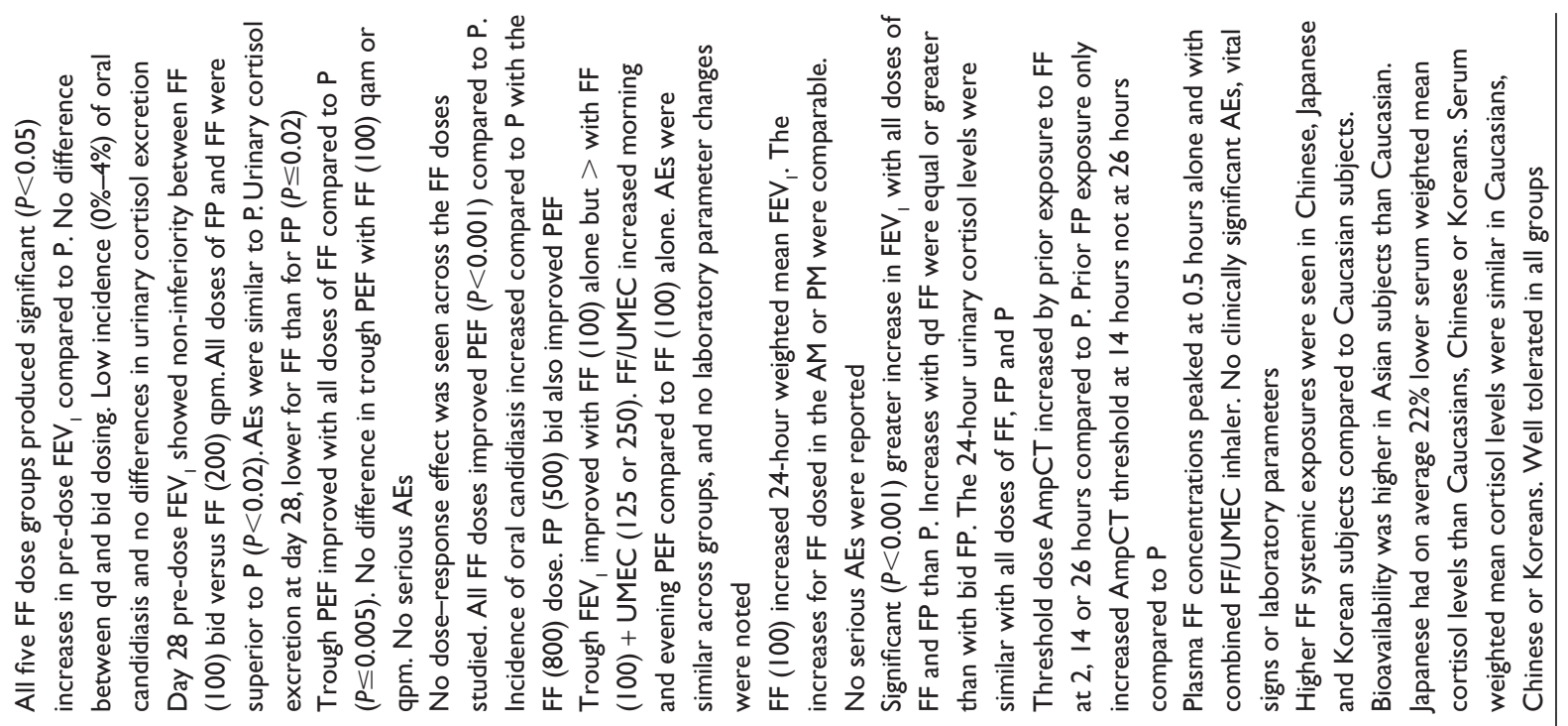

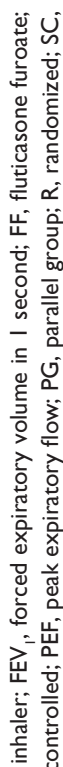

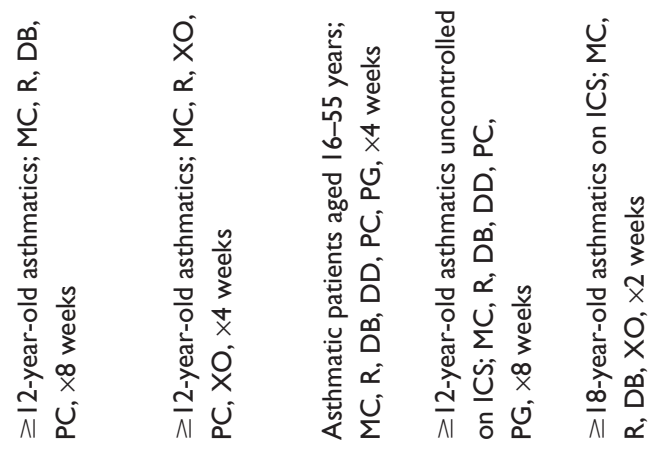

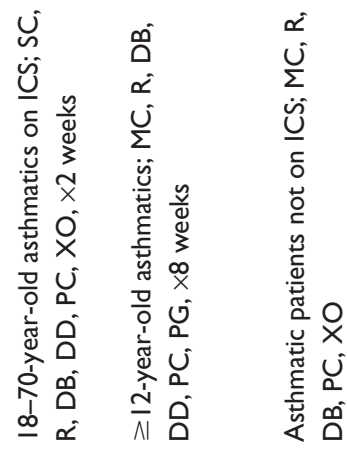

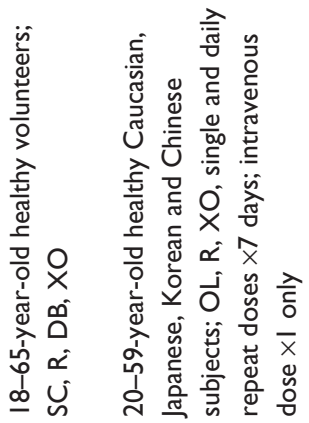

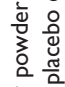

충

言总

䆣

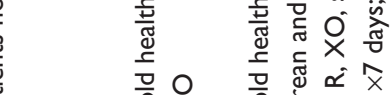

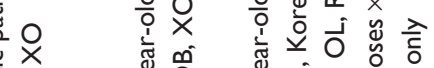

i ํํㅇ

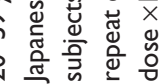

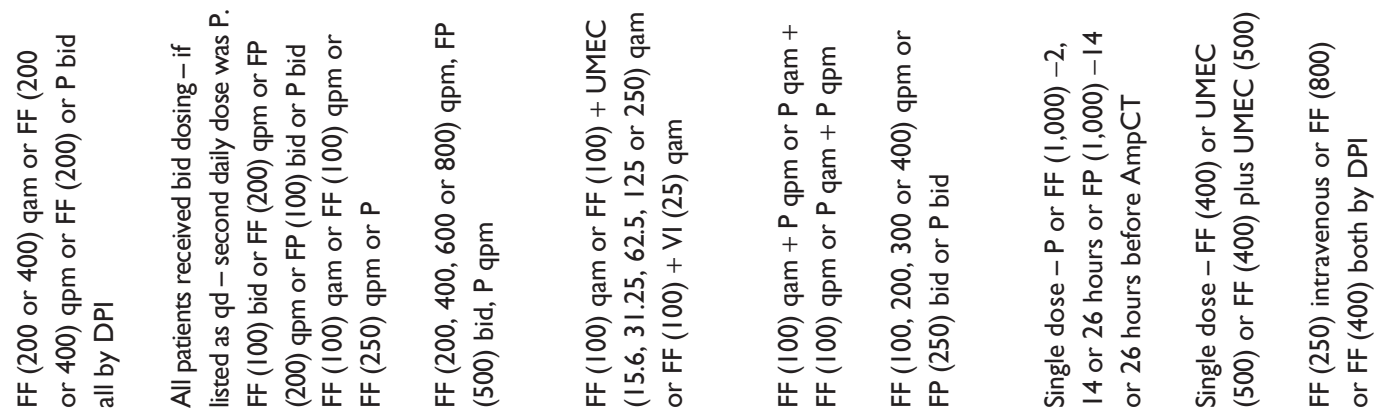

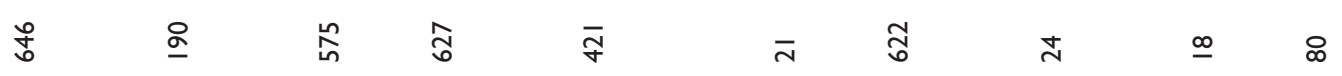

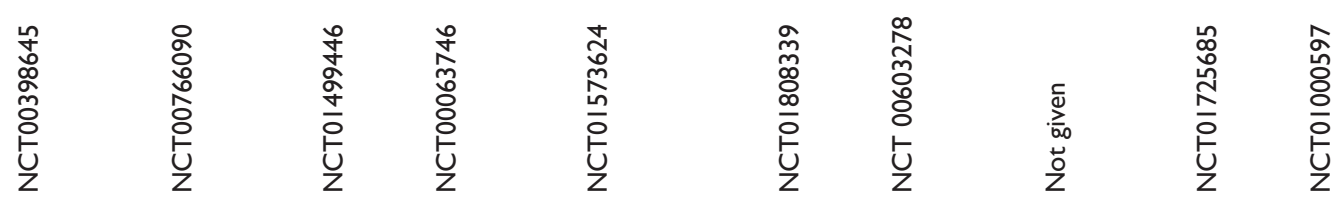

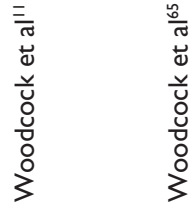

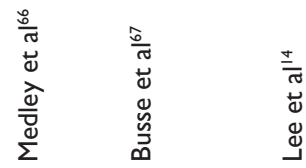

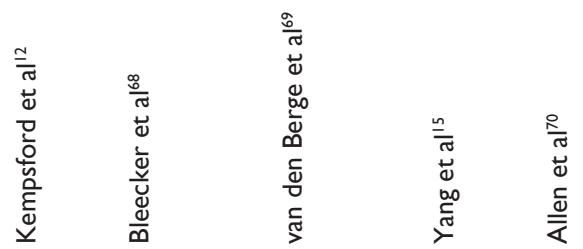

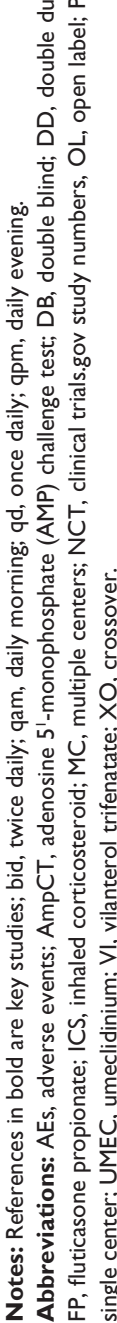


expiratory flow (PEF) and reported adverse events with the two FF doses. The $200 \mu \mathrm{g}$ FF-treated group was $42 \%$ more likely to have well-controlled symptoms than the $100 \mu \mathrm{g}$ FF-treated group. There were no safety concerns, and no clinically relevant effects on 24-hour urinary cortisol levels with either of the doses of inhaled FF were found. ${ }^{13}$

When inhaled FF (100 $\mu \mathrm{g})$ daily for 2 weeks was compared to FF $(100 \mu \mathrm{g})$ combined with the long-acting muscarinic antagonist (LAMA), umeclidinium (UMEC; 15.6, $31.25,62.5,125$ or $250 \mu \mathrm{g}$ ), in adult asthmatics, trough $\mathrm{FEV}_{1}$ was improved with FF $(100 \mu \mathrm{g})$ alone (by $87 \mathrm{~mL}$ ) compared to baseline, but they increased even more when FF $(100 \mu \mathrm{g})$ was combined with UMEC doses (141-214 mL). ${ }^{14}$ When least-squares mean change in trough $\mathrm{FEV}_{1}$ was evaluated, statistically significant differences were seen with FF $(100 \mu \mathrm{g}) / \mathrm{UMEC}(125$ and $250 \mu \mathrm{g}$; both $55 \mathrm{~mL}, P=0.018)$ compared to FF $(100 \mu \mathrm{g})$ alone. ${ }^{14}$ In addition, both morning and evening PEF improved more with the combination of FF with UMEC daily inhalation compared to FF alone. The FF serum concentrations peaked at half an hour when given alone, and this did not change when combined with UMEC. ${ }^{15}$ The use of daily FF given by DPI has a proven efficacy in asthmatic patients requiring an ICS for symptom control. The combination of FF with LAMA appears to increase the efficacy compared to FF alone in asthmatic patients.

\section{The use of VI in asthma}

Several new LABA agents designed for once-daily dosing are available or under study including indacaterol, olodaterol, abediterol and VI. ${ }^{16}$ Appropriate concern for the use of LABA agents alone as maintenance therapy has mandated that asthmatic subjects in most clinical studies evaluating the use of the inhaled LABA VI be currently on an ICS (Table 4). An exception is the study by Kempsford et al. ${ }^{17}$ Inhaled VI was given once daily $(25-100 \mu \mathrm{g})$ for 14 days to healthy volunteers and once to patients with either asthma or COPD. Inhaled VI was rapidly absorbed with a median time to maximal serum concentrations of 5 minutes in healthy subjects and 10 minutes for asthma and COPD patients. All VI doses improved FEV $\mathrm{Fy}_{1}$ 5 minutes and maintained increased $\mathrm{FEV}_{1}$ up to 24 hours after inhalation in patients with asthma or COPD. ${ }^{17}$ No clinically significant adverse effects were found including evaluations of vital signs, 12-lead electrocardiogram (ECG), Holter ECG, blood glucose or potassium levels. Table 4 summarizes five placebo-controlled clinical trials in asthmatics on an ICS that evaluated inhaled VI using a DPI device lasting between 1 and 12 weeks. Doses between 3 and $50 \mu \mathrm{g}$ daily of inhaled VI were tried, and the bronchodilator effect lasted at least 24 hours for
VI doses $12.5-50 \mu g .{ }^{18}$ The efficacy and safety of once-daily VI dosing in asthmatics were established by Sterling et al ${ }^{19}$ who evaluated 72 adult ( $\geq 18$ years old) asthmatics on an ICS with a 7-day treatment of daily inhaled VI (6.25, 12.5 and $25 \mu \mathrm{g})$, twice-daily inhaled VI $(6.25 \mu \mathrm{g})$ or placebo using a DPI. The VI treatment in asthmatics resulted in a statistically significant $(P<0.001$ for all doses) increase on day 7 in trough $\mathrm{FEV}_{1}$ and weighted mean 24-hour $\mathrm{FEV}_{1}$ versus placebo. The differences from placebo for trough $\mathrm{FEV}_{1}$ with once-daily VI were $94 \mathrm{~mL}(95 \% \mathrm{CI}=49-140 \mathrm{~mL}), 102 \mathrm{~mL}$ $(95 \% \mathrm{CI}=57-147 \mathrm{~mL})$ and $125 \mathrm{~mL}(95 \% \mathrm{CI}=80-170 \mathrm{~mL})$ for $6.25,12.5$ and $25 \mu \mathrm{g}$ doses, respectively. The $6.25 \mu \mathrm{g}$ VI twice-daily dose resulted in $140 \mathrm{~mL}(95 \% \mathrm{CI}=95-185 \mathrm{~mL})$ improvement in trough $\mathrm{FEV}_{1}$ compared to placebo. ${ }^{19}$ Noninferiority between once-daily versus twice-daily VI dosing was also shown. ${ }^{19}$

A recent large trial children aged 5-11 years $(\mathrm{N}=456)$ with persistent asthma symptoms inadequately controlled on an ICS were randomized to once-daily inhaled VI $(6.25,12.5$ or $25 \mu \mathrm{g}$ ), and this was compared to placebo over 4 weeks. It demonstrated safety but failed to show an improvement from baseline in trough $\mathrm{FEV}_{1}$ for any of the VI doses tested. ${ }^{20}$ Adult asthmatic patients uncontrolled on an ICS ( $N=347)$ were given once-daily VI $(25 \mu \mathrm{g})$ for 12 weeks and were compared to those given twice-daily SAL or placebo. Researchers noted the improvement in $\mathrm{FEV}_{1}$ of $359 \pm 42.9 \mathrm{~mL}$ with VI, $283 \pm 41.9 \mathrm{~mL}$ with SAL and $289 \pm 42.9 \mathrm{~mL}$ for placebo. ${ }^{21}$ The increase in $\mathrm{FEV}_{1}$ was not statistically significantly different between VI and placebo. Overall, these data suggest that there is a variable response to inhaled VI in adult patients with persistent symptoms already on an ICS and even less efficacy of VI in asthmatic children on an ICS.

\section{The use of FF and $V I$ in asthma}

Pharmacodynamic, pharmacokinetic and safety data have been tested with inhaled FF/VI in several populations, including healthy Chinese and Japanese, in patients simultaneously on ketoconazole and in patients with renal and hepatic impairment. ${ }^{22-25}$ Stable pharmacokinetics and pharmacodynamics and no safety concerns over the use of inhaled FF/VI were found in these studies. Allergen and methacholine challenge tests were used in 27 patients randomized to inhaled FF $(100 \mu \mathrm{g})$, VI $(25 \mu \mathrm{g})$, FF (100 $\mu \mathrm{g}) / \mathrm{VI}$ $(25 \mu \mathrm{g})$ or placebo. ${ }^{26}$ Using the allergen challenge to test early asthmatic response (EAR) and airway hyperresponsiveness (AHR), researchers found a decrease in $\mathrm{FEV}_{1}$. Using the mean 0-2 hours post allergen challenge $\mathrm{FEV}_{1}$, the least decrease was reported with the pre-challenge dosing of the 
Table 4 Major clinical trials with VI in asthma

\begin{tabular}{|c|c|c|c|c|c|}
\hline Study & Trial number & $\mathbf{N}$ & Drugs $(\mu \mathrm{g})$ & Design & Results (doses in $\mu \mathrm{g}$ ) \\
\hline $\begin{array}{l}\text { Kempsford } \\
\text { et al }{ }^{77}\end{array}$ & $\begin{array}{l}\text { NCT00469040; } \\
\text { NCT00463697; } \\
\text { NCT00519376; } \\
\text { NCT00702910 }\end{array}$ & $\begin{array}{l}36,22 \\
\text { and } 24\end{array}$ & $\begin{array}{l}\mathrm{VI}(25) \text { or } \mathrm{VI}(50) \text { or } \\
\mathrm{VI}(\mathrm{I00}) \text { or } \mathrm{P} \text { all daily } \\
\text { and } \mathrm{VI}(25) \text { or } \mathrm{VI}(50) \\
\text { or } \mathrm{VI}(\mathrm{I00}) \text { or } \mathrm{P} \text { single } \\
\text { dose and } \mathrm{VI}(6.25) \text { or } \mathrm{VI} \\
(25) \text { or } \mathrm{VI}(100) \text { or } \mathrm{P} \text { all } \\
\text { single dose, all by DPI }\end{array}$ & $\begin{array}{l}\text { Healthy subjects ( } 36 \text { ) between } \\
18 \text { and } 55 \text { years old, SC, PC, } \\
\mathrm{R}, \mathrm{DB}, \mathrm{PG}, \times 14 \text { days and } \\
\text { persistent asthmatics }(22) \\
\geq 18 \text { years old, MC, R, DB, PC, } \\
\mathrm{XO} \text {, single dose and persistent } \\
\text { asthmatics ( } 24 \text { ) between } 18 \text { and } \\
55 \text { years old, MC, R, DB, PC, } \\
\mathrm{XO} \text {, single dose }\end{array}$ & $\begin{array}{l}\text { VI rapidly absorbed maximal } \\
\text { concentration between } 5 \text { and } \\
10 \text { minutes. No significant changes } \\
\text { in vital signs, I } 2 \text {-lead ECG or blood } \\
\text { chemistry changes were noted } \\
\text { with VI. All doses of VI resulted in } \\
\text { increases in FEV, within } 5 \text { minutes } \\
\text { and lasted at least } 24 \text { hours }\end{array}$ \\
\hline Lötvall et al ${ }^{21}$ & NCT0II8I895 & 347 & $\begin{array}{l}\mathrm{VI}(25) \text { daily SAL }(50) \\
\text { bid or P, all by DPI }\end{array}$ & $\begin{array}{l}\text { Adult asthmatics uncontrolled } \\
\text { by ICS alone; MC, R, PC, DB, } \\
\text { DD, } \times 12 \text { weeks }\end{array}$ & $\begin{array}{l}\mathrm{VI}, \mathrm{SAL} \text { and } \mathrm{P} \text { all showed substantial } \\
\text { improvement in } 24 \text {-hour weighted } \\
\text { mean } \mathrm{FEV} \text {, after } 12 \text { weeks without } \\
\text { statistically significant differences. } \\
\text { Low rates of } A E s \text { compared to } \mathrm{P}\end{array}$ \\
\hline Oliver et $\mathbf{a l}^{20}$ & NCT0I573767 & 456 & $\begin{array}{l}\mathrm{VI}(6.25,12.5 \text { or } 25) \\
\text { or P Daily, all by DPI, } \\
\text { all replaced their ICS } \\
\text { with FP }(100) \text { bid during } \\
\text { 4-week run-in phase }\end{array}$ & $\begin{array}{l}\text { Children aged 5-II years with } \\
\text { persistent asthma on ICS; MC, } \\
\text { R, DB, PC, PG, } \times 4 \text { - and I-week } \\
\text { follow-up }\end{array}$ & $\begin{array}{l}\text { The adjusted mean change from } \\
\text { baseline in evening PEF averaged } \\
\text { over the 4-week treatment phase } \\
\text { showed no significant difference } \\
\text { between } \mathrm{VI} \text { and } \mathrm{P} \text {. No difference was } \\
\text { also seen in trough FEV, between } \mathrm{VI} \\
\text { and } \mathrm{P} \text {. VI resulted in an additional } 0.6 \\
\text { rescue-free days and } 0.7 \text { symptom- } \\
\text { free days per week compared to } \mathrm{P} \text {. } \\
\text { AEs were slightly higher with } \mathrm{VI} \\
(28 \%-33 \%) \text { versus } \mathrm{P}(22 \%)\end{array}$ \\
\hline Lötvall et al ${ }^{18}$ & NCT00600I7I & 614 & $\begin{array}{l}\mathrm{VI}(3,6.25,12.5,25 \text { or } \\
50) \text { or P qPm, by DPI }\end{array}$ & $\begin{array}{l}\geq 12 \text {-year-old symptomatic } \\
\text { asthmatics on stable ICS dose; } \\
\text { MC, } R, D B, P \text {, dose-ranging } \\
\text { study, } \times 28 \text { days }\end{array}$ & $\begin{array}{l}\text { A VI dose-response effect }(P=0.037) \\
\text { was seen on improving trough } F E V_{1} \text {. } \\
\text { Statistically significant }(P \leq 0.016) \\
\text { increases in mean } \mathrm{FEV}, \text { relative to } P \\
\text { were seen for } \mathrm{VI} \text { doses }(12,25 \\
\text { and } 50) \text {. Prolonged bronchodilation } \\
\text { was seen for at least } 24 \text { hours with } \mathrm{VI}\end{array}$ \\
\hline Sterling et a $^{19}$ & NCT00980200 & 75 & $\begin{array}{l}\mathrm{VI}(6.25) \text { daily or } \mathrm{VI} \\
\text { (6.25) bid or VI (I2.5) } \\
\text { daily or VI ( } 25) \text { daily } \\
\text { or P, all by DPI }\end{array}$ & $\begin{array}{l}\geq 18 \text {-year-old asthmatics on } \\
\text { stable dose ICS; MC, R, DB, } \\
P C, X O, \times 7 \text { days }\end{array}$ & $\begin{array}{l}\text { All } \mathrm{VI} \text { doses had significant }(P<0.00 \mathrm{I}) \\
\text { increase in weighted mean } 24 \text {-hour } \\
\mathrm{FEV} \text {, compared to } P \text {. Low incidence } \\
\text { of AEs with } \mathrm{VI}(5 \%-9 \%) \text { without } \\
\text { evidence of dose dependence. } \\
\mathrm{PAEs} \text { were } 18 \%\end{array}$ \\
\hline Oliver et $\mathrm{al}^{71}$ & NCT0I453296 & 28 & $\begin{array}{l}\text { VI }(25) \text { or } \mathrm{P} \text { single dose } \\
\text { and } \mathrm{VI}(25) \text { or } \mathrm{P} \text { daily, } \\
\text { all by DPI }\end{array}$ & $\begin{array}{l}\text { Children aged } 5-1 \text { I years with } \\
\text { persistent asthma on ICS; MC, } \\
R, D B, P C, X O \text {, single dose } \\
\text { then } 7 \text { days later, once-daily } \\
\text { dosing, } \times 7 \text { days }\end{array}$ & $\begin{array}{l}\text { All ages showed similar } \mathrm{VI} \\
\text { pharmacokinetics. No laboratory or } \\
\text { ECG abnormalities. No change in } \\
\text { PEF from day I to day } 14\end{array}$ \\
\hline
\end{tabular}

Notes: References in bold are key studies; bid, twice daily; qpm, daily evening.

Abbreviations: AEs, adverse events; DB, double blind; DD, double dummy; DPI, dry powder inhaler; ECG, electrocardiogram; FEV , forced expiratory volume in I second; FP, fluticasone propionate; ICS, inhaled corticosteroid; MC, multicenter; P, placebo; PC, placebo controlled; PEF, peak expiratory flow; PG, parallel group; R, randomized; $\mathrm{SAL}$, salmeterol; SC, single center; $\mathrm{VI}$, vilanterol trifenatate; $\mathrm{XO}$, crossover.

combination $\mathrm{FF} / \mathrm{VI}$ inhaler $(-0.614 \mathrm{~L}, 95 \% \mathrm{CI}=-0.858$ to -0.370$)$ and the greatest decrease was after placebo inhaler $(-1.091 \mathrm{~L}, 95 \% \mathrm{CI}=-1.344$ to -0.837$)$. The methacholine challenge test was used in these patients to model late asthmatic response (LAR) and AHR at 24 hours. Weighted mean $\mathrm{FEV}_{1}$ 4-10 hours post challenge was reduced after placebo $(-466 \mathrm{~mL}, 95 \% \mathrm{CI}=-589$ to -343$)$ but actually increased with FF (100 $\mu \mathrm{g} ; 18 \mathrm{~mL}, 95 \% \mathrm{CI}=-89$ to 125$)$ and with $\mathrm{FF}(100 \mu \mathrm{g}) / \mathrm{VI}(25 \mu \mathrm{g} ; 18 \mathrm{~mL}, 95 \% \mathrm{CI}=-89$ to 124). It was also improved compared to placebo with VI $(25 \mu \mathrm{g} ;-298 \mathrm{~mL}, 95 \% \mathrm{CI}=-415$ to -181$) .{ }^{26}$ The use of the combined FF/VI provided statistically significant protection against the EAR of AHR compared to its components alone and to placebo. There was also statistically significant protection with combination FF/VI therapy when compared to placebo and VI alone against the LAR of AHR. 
Cytochrome P450 3A4 (CYP3A4) is the major hepatic enzyme responsible for metabolizing FF by ester hydrolysis with the formation of the 17 beta-carboxylic acid and loss of the $S$-fluoro-methyl-carbothioate. ${ }^{24,27} \mathrm{FF}$ is also believed to be a substrate for the P-glycoprotein (PgP) efflux transporter, and enterocytes may have a major metabolic effect on FF in the gastrointestinal track. ${ }^{27}$ The hepatic enzyme CYP3A4 also plays a major role in the metabolism of VI by $O$-dealkylation. ${ }^{28} \mathrm{It}$ is also believed to be a substrate for $\mathrm{PgP}$ when in the gastrointestinal system. ${ }^{24}$ Ketoconazole is a probe used to assess the potential effect of CYP3A4 metabolic inhibition, and it also has inhibitory effects on $\mathrm{PgP} .{ }^{24}$ Coadministration of repeat doses of ketoconazole $400 \mathrm{mg}$ daily and inhaled VI $(25 \mu \mathrm{g})$ alone had no pharmacodynamic or pharmacokinetic effect on VI. When 11 days of $400 \mathrm{mg}$ oral ketoconazole daily was coadministered with inhaled $\mathrm{FF}(200 \mu \mathrm{g}) / \mathrm{VI}(25 \mu \mathrm{g})$ from days 5 to 11 , no statistical or clinical effect was seen on heart rate or minimal potassium levels. ${ }^{24}$ There was a $27 \%$ decrease in 24 -hour weighted mean serum cortisol levels (treatment ratio $=0.73,90 \%$ $\mathrm{CI}=0.62-0.86$ ). An increase in the FF area under the plasma concentration $0-24$-hour curve by $36 \%$ with ketoconazole $(90 \% \mathrm{CI}=16 \%-59 \%)$ was reported. The area under the plasma concentration 0-24-hour VI curve increased by $65 \%$ $(90 \% \mathrm{CI}=38 \%-97 \%) .{ }^{24}$ Table 5 summarizes the major pharmacokinetic parameters of FF and VI that allow once-daily dosing for this inhaled fixed combination medication.

Table 6 summarizes the major clinical trials evaluating pharmacokinetics, safety and efficacy of FF/VI given by DPI in asthmatic patients. Large randomized double-blind clinical trials have shown improved $\mathrm{FEV}_{1}$ and PEF measures by treatment with FF/VI compared to placebo or the same or better measures with active control agents such as inhaled FP and FP with the LABA SAL twice daily. ${ }^{29-36}$ These clinical trials lasted from 2 to 52 weeks and evaluated efficacy and safety. Two trials each of 12-week duration have confirmed the efficacy of FF (100-200 $\mu \mathrm{g}) / \mathrm{VI}(25 \mu \mathrm{g})$ given daily by DPI in Asian asthmatic patients compared to placebo ${ }^{37}$ and compared to the active comparator FP using PEF measures of efficacy. ${ }^{38}$

An observational study from Italian National Health Service data used propensity score matching on baseline covariates of gender, age, $\mathrm{FEV}_{1}$ and comorbidities on 40 adult asthmatic patients. They were treated with FF $(100 \mu \mathrm{g}) /$ VI $(25 \mu \mathrm{g})$ by DPI once daily or beclomethasone dipropionate/formoterol (BEC/F) inhalation twice daily. ${ }^{39}$ The BEC/F-treated group had $0.28( \pm 0.12)$ days of hospitalization, and those treated with FF/VI had $0.08( \pm 0.04)$ days of hospitalization $(P=0.09)$ during the 12 -week analysis period. Both the number of physician visits and the number of specialist visits were statistically reduced in the $\mathrm{FF} /$ VI-treated group compared to the BEC/F-treated group. ${ }^{39}$ Another small comparison study $(\mathrm{N}=30)$ in Japan evaluated BUD $(160 \mu \mathrm{g}) / \mathrm{F}(4.5 \mu \mathrm{g})$ two puffs twice daily and one additional inhalation as needed of BUD/F each day versus FF $(100 \mu \mathrm{g}) / \mathrm{VI}(25 \mu \mathrm{g})$ by DPI daily over 4 weeks in asthmatics $\geq 20$ years who required an ICS. ${ }^{40}$ Both drug combinations showed statistically significant $(P<0.001)$ improvement in the asthma control questionnaire during the 4 weeks with greater improvement in the scores with the BUD/F-treated group. Both groups also showed decreases $(P<0.001)$ in fractional exhaled nitric oxide (FeNO) from baseline to week 4 with the levels in the BUD/F group reduced greater $(P<0.001)$ than the FF/VI-treated group. The use of a fixeddose ICS/LABA as a rescue medication in this study goes against historical dogma of using SABA agents as rescue medication in asthma but is in the GINA guidelines (Table 1). In addition, direct comparisons between different combinations of ICS/LABA beg the question of dosage equivalence. In this study, perhaps the comparator should have been FF $(200 \mu \mathrm{g}) / \mathrm{VI}(25 \mu \mathrm{g})$ as a high-dose ICS as opposed to the low-dose FF $(100 \mu \mathrm{g}) / \mathrm{VI}(25 \mu \mathrm{g})$ combination.

The asthma-COPD overlap syndrome (ACOS) is an asthma phenotype that shares features of both asthma and traditional COPD. ${ }^{1,41}$ A small ( $\left.\mathrm{N}=16\right)$ open-label, randomized, crossover study of patients with ACOS in Japan compared

Table 5 Pharmacokinetics of FF and VI

\begin{tabular}{|c|c|c|c|c|c|}
\hline Drug & $\begin{array}{l}\text { Mean absorption } \\
\text { time (IN) (hours) }\end{array}$ & $\begin{array}{l}\text { Absolute bioavailability } \\
\text { (IN) (\%) }\end{array}$ & $t_{\max }$ (IN) (hours) & $t_{1 / 2}$ beta (hours) & VD (IN) (L) \\
\hline $\mathrm{FF}$ & $10.53(8.52-13.01)$ & $6.3-18.4 ; 15.2(12.6-18.4)$ & $\begin{array}{l}1.0(0.08-4.00) \text { to } \\
0.08(0.08-1.50)\end{array}$ & $\begin{array}{l}23.7(20.8-26.9)(\mathrm{IN}) \\
\text { I5.4 (I3.I-I8.2) (IV) }\end{array}$ & $661(546-800)$ \\
\hline VI & $0.659(0.286-1.517)$ & $10-12 ; 27.3(21.6-34.6)$ & $\begin{array}{l}0.150(0.08-0.17) \text { to } \\
0.100(0.08-0.18)\end{array}$ & $\begin{array}{l}2.47(\mathrm{I} .65-3.70)(\mathrm{IN}) \\
2.40(\mathrm{I} .65-3.48)(\mathrm{IV})\end{array}$ & $165(129-211)$ \\
\hline
\end{tabular}

Notes: Data are mean $(90 \% \mathrm{Cl}) ; t_{\max }$, time to maximum observed concentration (inhaled); $t_{1 / 2}$ beta, terminal elimination half-life. Data from. ${ }^{10,70,72,73}$

Abbreviations: $\mathrm{Cl}$, confidence interval; FF, fluticasone furoate; IN, inhaled dose; IV, intravenous dose; L, liters; VD, volume of distribution at steady state; VI, vilanterol trifenatate. 


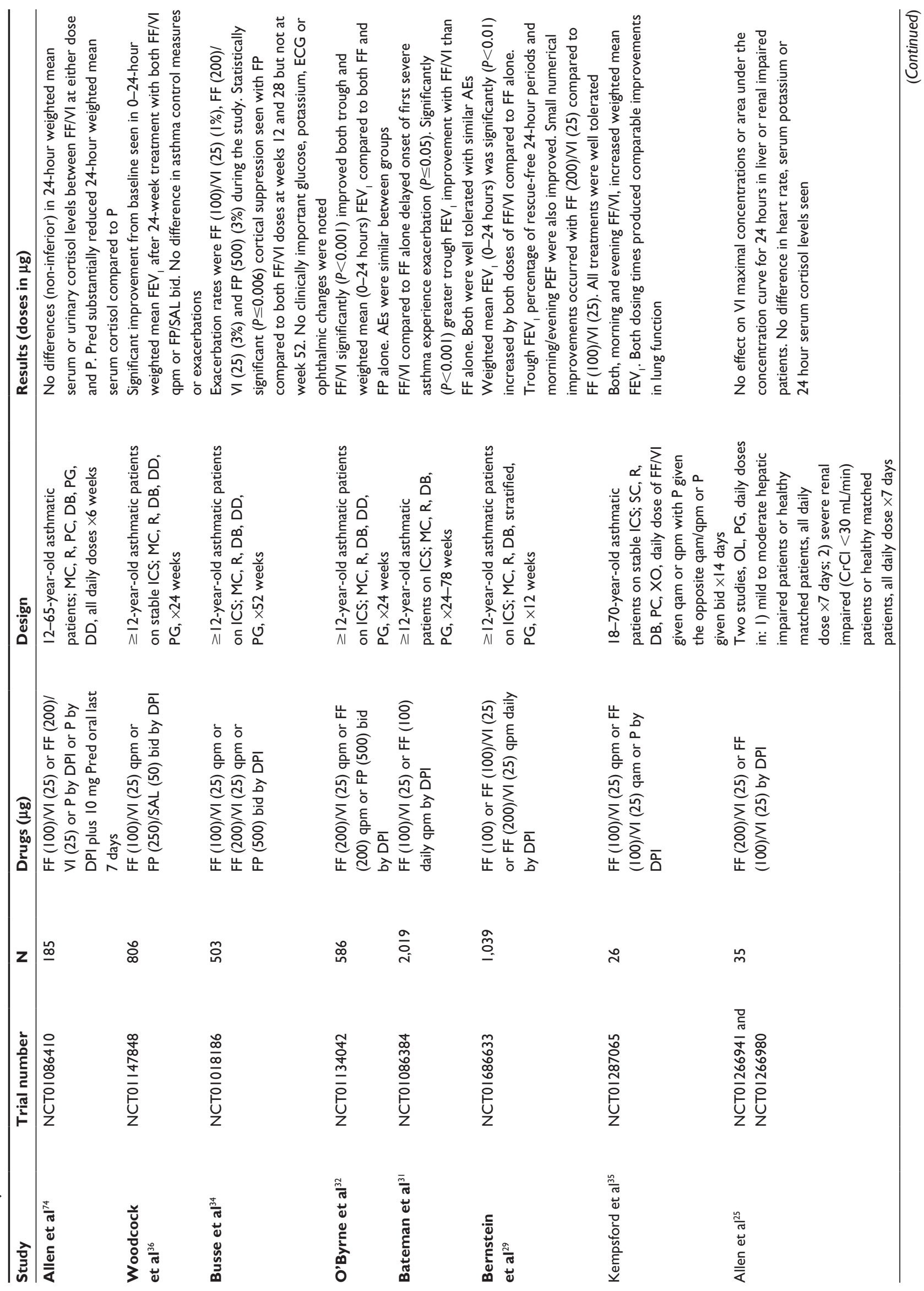




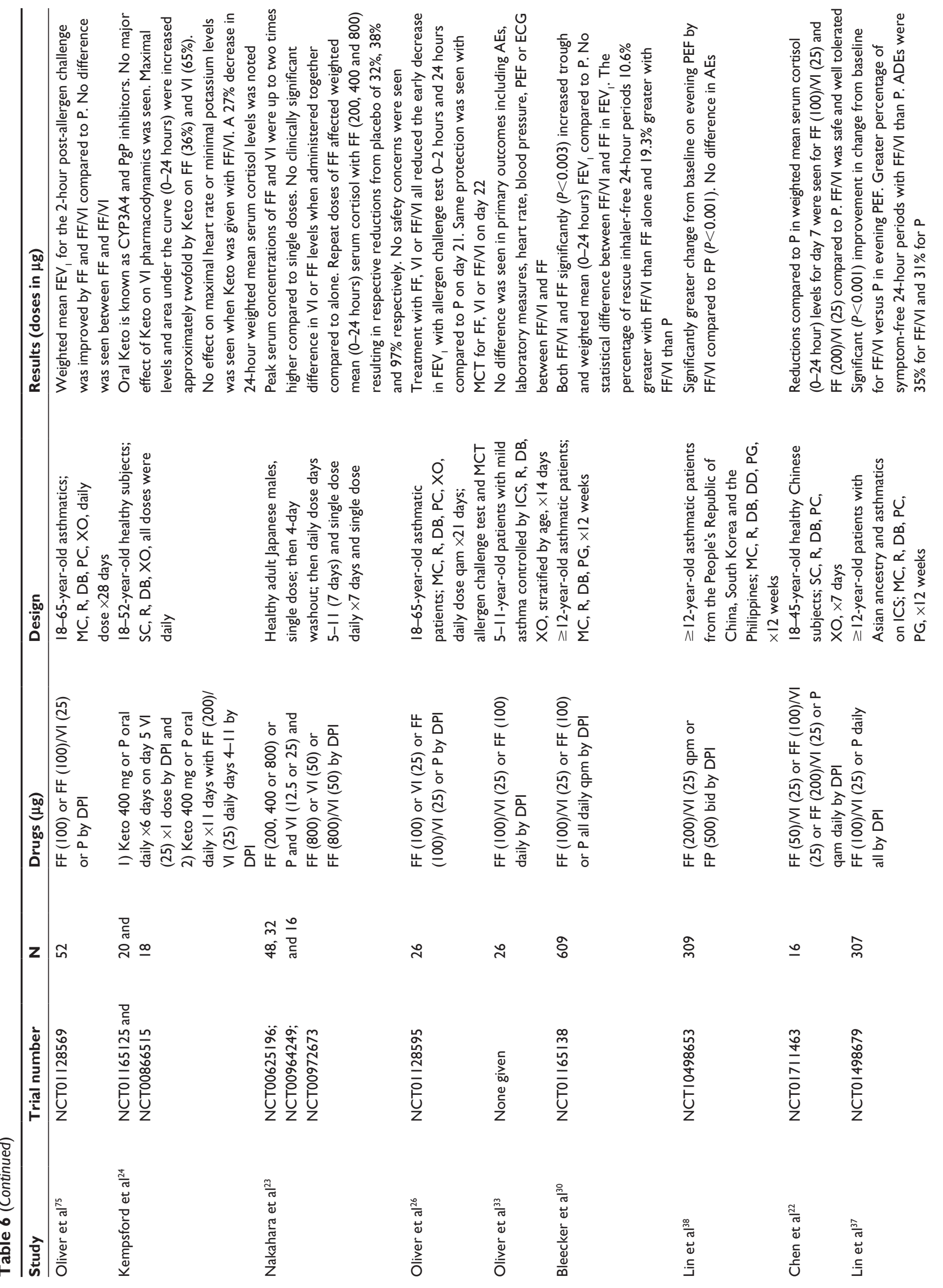



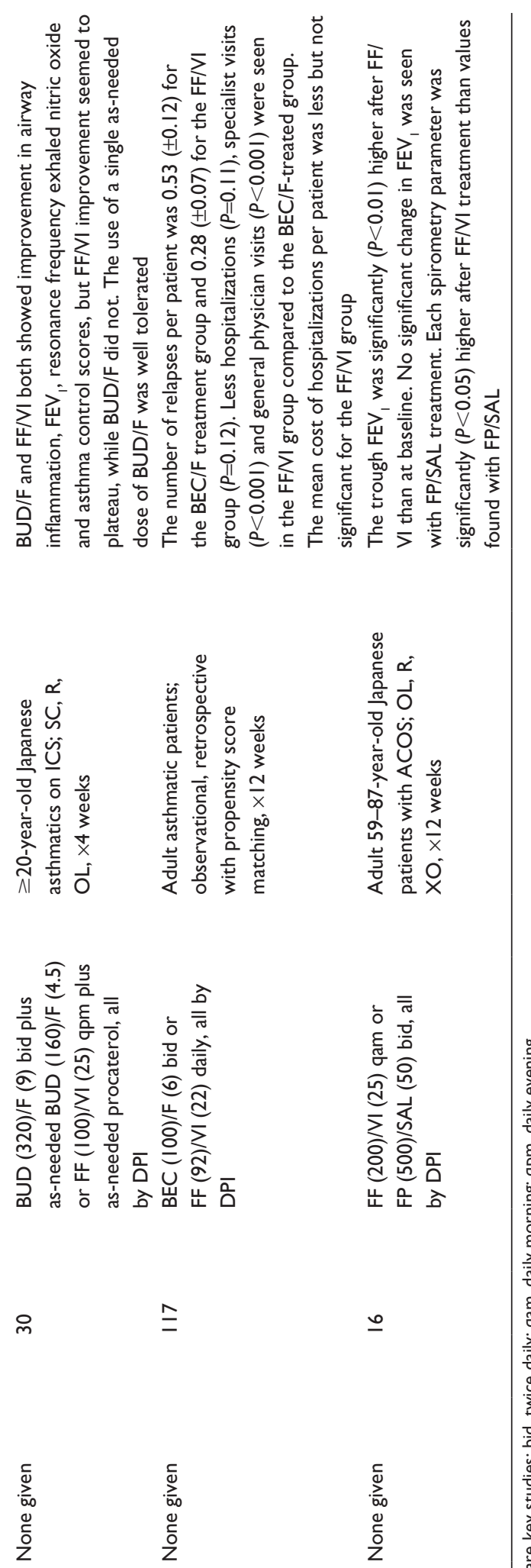

$\frac{1}{0}$
200
0
0
$Z$
$Z$

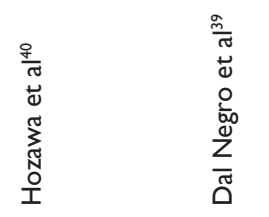

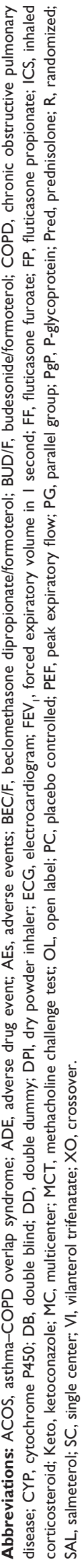

once-daily FF $(200 \mu \mathrm{g}) / \mathrm{VI}(25 \mu \mathrm{g})$ versus FP $(500 \mu \mathrm{g}) / \mathrm{SAL}$ $(50 \mu \mathrm{g})$ twice daily for 4 -week treatment periods. ${ }^{42}$ The mean value of $\mathrm{FEV}_{1}$ was $1.33 \mathrm{~L}( \pm 1.29)$ during the run-in period, $138 \mathrm{~L}( \pm 0.39)$ after the FP/SAL treatment and $1.47( \pm 0.38)$ $\mathrm{L}$ after the FF/VI treatment. The mean value of $\mathrm{FEV}_{1}$ was significantly $(P<0.01)$ greater in the $\mathrm{FF} / \mathrm{VI}$ treatment group compared to the run-in period in these patients with ACOS. Although a small trial of short duration, it is one of the few pharmacological trials in patients with ACOS and the only randomized trial evaluating the FF/VI combination inhaler in patients with ACOS phenotype.

A large pragmatic study evaluating FF (100 or $200 \mu \mathrm{g}) /$ VI $(25 \mu \mathrm{g})$ inhaler use versus existing asthma maintenance therapies is ongoing. The Salford Lung Study is a randomized and controlled trial started before FF/VI inhalers were approved for asthma treatment. It utilizes the Salford electronic medical record to give near real-time data collection and monitoring of safety data at 66 primary care sites in and around Salford and South Manchester, England. ${ }^{43}$ The data from this study when available will complement the more standard double-blind, randomized, controlled trials evaluating real-world efficacy and obtaining risk/benefit information on inhaled FF/VI.

When East Asian patients were compared to non-East Asian patients from the large randomized, double-blind, multicenter clinical trials in a prespecified subgroup analysis, both FF (100 or $200 \mu \mathrm{g}) / \mathrm{VI}(25 \mu \mathrm{g})$ dose combinations were as effective in improving $\mathrm{FEV}_{1}$ compared to placebo as in non-East Asian patients. ${ }^{44}$ A systematic review with meta-analysis of seven published trials $(\mathrm{N}=5,668)$ evaluating inhaled $\mathrm{FF} / \mathrm{VI}$ in asthmatic patients was recently performed. ${ }^{45}$ The combination therapy of FF (100 or $200 \mu \mathrm{g}$ )/ VI $(25 \mu \mathrm{g})$ daily increased trough $\mathrm{FEV}_{1}$ in asthmatics treated longer than 8 weeks compared to either FP twice daily or FF daily alone. Three of the seven trials compared FF (100 or $200 \mu \mathrm{g}) / \mathrm{VI}(25 \mu \mathrm{g})$ doses to FF $(100 \mu \mathrm{g})$ once daily and showed a significant $(P \leq 0.001)$ increase in trough $\mathrm{FEV}_{1}$ of $90 \mathrm{~mL}(95 \% \mathrm{CI}=60-120 \mathrm{~mL})$ with the combination inhaler compared to $\mathrm{FF}$ alone. ${ }^{45}$

\section{Medication adherence with inhalers}

Medication adherence or following the medication plan is a significant problem and factor in the treatment of chronic diseases ${ }^{46}$ Dosing frequency has a major effect on the rate of nonadherence of medication in chronic diseases. ${ }^{47}$ When medications are given twice daily compared to once daily, the adherence rates were significantly lower, with regimen adherence reduced by $13.1 \%$ and timing adherence reduced 
by $26.7 \%$ compared to once daily. ${ }^{47}$ The adherence rates fall $23.1 \%$ for regimen adherence and $54.2 \%$ for timing adherence when medications are given four times daily compared to daily dosing. Nonadherence to treatment is associated with poor baseline asthma control. ${ }^{48,49}$ The nonadherence rates among asthmatic patients range between $30 \%$ and $70 \%$, and because of this the assessment of medication adherence is a critical part of evaluating the difficult to treat asthma patient. ${ }^{50,51}$ Integrated and innovative approaches to patients are needed to improve medication adherence in difficult asthmatic patients. ${ }^{52}$ Oncedaily medications and the combination of an ICS with a LABA in a single inhaler are associated with improved medication adherence compared to that of an ICS alone. ${ }^{53,54}$ Better medication adherence must be addressed and will improve health outcomes and asthma disease control. ${ }^{55,56}$

In addition to being a daily combination dosing asthma maintenance medication, Breo Ellipta (GSK) utilizes the Ellipta delivery system. The Ellipta dry powder system (GSK, UK and Japan) has been shown to be easy to use and preferred over the Breezhaler (Novartis Pharma UK, Japan) in device-naive Japanese volunteers. ${ }^{57}$ When semi-structured, in-depth, qualitative interviews were conducted on asthma and COPD patients after using Ellipta (GSK, Germany) dry powder inhalation systems, the Ellipta device was associated with the highest patient satisfaction and preference. ${ }^{58}$ Patient preference for the Ellipta device was also demonstrated in 287 COPD patients randomized to the Ellipta or Diskus DPIs. ${ }^{59}$ The Ellipta device was significantly preferred $(P<0.001)$ over the Diskus device in all categories. Overall inhaler preference was $67 \%$ for the Ellipta device and $31 \%$ for the Diskus. ${ }^{59}$ Once-daily dosing with the FF/VI Ellipta device and its high patient preference are also likely to contribute to improved asthma medication adherence.

To date, a large amount of clinical trial data exists supporting the efficacy and safety of the use of inhaled FF/VI by DPI for asthma maintenance treatment. The combination ICS/LABA of FF/VI fits well into the GINA guidelines starting as early as step $3 .{ }^{1}$ Studies looking at a fixed-dose triplecombination inhaler with FF, VI and the LAMA UMEC are ongoing in healthy volunteers, being developed for COPD indication and could be evaluated in asthmatic patients. ${ }^{60}$

\section{Conclusion}

The DPI inhaler, FF/VI, is a fixed combination of two strengths of FF (100 or $200 \mu \mathrm{g})$ both with VI $(25 \mu \mathrm{g})$ used as a maintenance treatment in asthmatic patients not controlled on just an ICS therapy alone. The doses of FF cover low- and high-dose ICS categories and fit nicely into the current GINA asthma treatment guidelines. Clinical trials have focused on each of the components of the combination inhaler. Efficacy and safety were demonstrated with inhaled FF in asthmatic patients. Similarly, efficacy and safety were demonstrated in clinical trials in adolescent and adult asthmatic patients on an ICS with adding inhaled VI but not in children aged 5-11 years. The data supporting the combined use of FF/VI in asthmatic patients requiring ICS are strong and document its efficacy and safety in long-term, large and randomized clinical trials in adolescents and adults. Pharmacokinetics and pharmacodynamics have been well studied and have demonstrated limited clinically important drug interactions (eg, ketoconazole) and minimal alterations from renal and liver impairments. Limited efficacy data with inhaled FF/VI exist for asthmatic children ( $<12$ years). Further studies on asthmatic children and various asthma phenotypes such as patients with ACOS are needed to better understand the full spectrum of the use of inhaled fixed combination FF/VI in the maintenance treatment of asthma.

\section{Disclosure}

The authors report no conflicts of interest in this work.

\section{References}

1. Asthma GINA Guidelines [homepage on the Internet]. Pocket Guide for Asthma Management and Prevention. 2016. Available from: www. ginasthma.org. Accessed September 1, 2016.

2. US FDA [database on the Internet]. 2016; Available from: https://www. accessdata.fda.gov/scripts/cder/drugsatfda/. Accessed September 1, 2016.

3. Castle W, Fuller R, Hall J, Palmer J. Serevent nationwide surveillance study: comparison of salmeterol with salbutamol in asthmatic patients who require regular bronchodilator treatment. BMJ. 1993; 306(6884):1034-1037.

4. Nelson HS, Weiss ST, Bleecker ER, Yancey SW, Dorinsky PM, Group SS. The Salmeterol Multicenter Asthma Research Trial: a comparison of usual pharmacotherapy for asthma or usual pharmacotherapy plus salmeterol. Chest. 2006;129(1):15-26.

5. Peters SP, Bleecker ER, Canonica GW, et al. Serious asthma events with budesonide plus formoterol vs. budesonide alone. N Engl J Med. 2016; 375(9):850-860.

6. Stempel DA, Raphiou IH, Kral KM, et al. Serious asthma events with fluticasone plus salmeterol versus fluticasone alone. N Engl J Med. 2016; 374(19):1822-1830.

7. Stempel DA, Szefler SJ, Pedersen S, et al. Safety of adding salmeterol to fluticasone propionate in children with asthma. N Engl J Med. 2016; 375(9):840-849.

8. Bush A, Frey U. Safety of long-acting beta-agonists in children with asthma. N Engl J Med. 2016;375(9):889-891.

9. Syed YY. Fluticasone furoate/vilanterol: a review of its use in patients with asthma. Drugs. 2015;75(4):407-418.

10. Allen A, Bareille PJ, Rousell VM. Fluticasone furoate, a novel inhaled corticosteroid, demonstrates prolonged lung absorption kinetics in man compared with inhaled fluticasone propionate. Clin Pharmacokinet. 2013; 52(1):37-42.

11. Woodcock A, Bateman ED, Busse WW, et al. Efficacy in asthma of once-daily treatment with fluticasone furoate: a randomized, placebocontrolled trial. Respir Res. 2011;12:132. 
12. Kempsford RD, Bal J, Baines A, Renaux J, Ravindranath R, Thomas PS The efficacy of fluticasone furoate administered in the morning or evening is comparable in patients with persistent asthma. Respir Med. 2016;112:18-24.

13. Woodcock A, Lotvall J, Busse WW, et al. Efficacy and safety of fluticasone furoate 100 mug and 200 mug once daily in the treatment of moderate-severe asthma in adults and adolescents: a 24-week randomised study. BMC Pulm Med. 2014;14:113.

14. Lee LA, Yang S, Kerwin E, Trivedi R, Edwards LD, Pascoe S. The effect of fluticasone furoate/umeclidinium in adult patients with asthma: a randomized, dose-ranging study. Respir Med. 2015;109(1):54-62.

15. Yang S, Lee L, Mallett S, Ayer J, Wolstenholme A, Pascoe S. A randomized, crossover study to investigate the pharmacokinetics and safety of inhaled fluticasone furoate and umeclidinium, administered separately and in combination via dry powder inhaler in healthy adult volunteers. Adv Ther. 2015;32(2):157-171.

16. Aparici M, Gavalda A, Ramos I, et al. In vitro and in vivo preclinical profile of abediterol (LAS100977), an inhaled long-acting beta2-adrenoceptor agonist, compared with indacaterol, olodaterol and vilanterol. Eur J Pharmacol. 2016;770:61-69.

17. Kempsford R, Norris V, Siederer S. Vilanterol trifenatate, a novel inhaled long-acting beta2 adrenoceptor agonist, is well tolerated in healthy subjects and demonstrates prolonged bronchodilation in subjects with asthma and COPD. Pulm Pharmacol Ther. 2013;26(2):256-264.

18. Lötvall J, Bateman ED, Bleecker ER, et al. 24-h duration of the novel LABA vilanterol trifenatate in asthma patients treated with inhaled corticosteroids. Eur Respir J. 2012;40(3):570-579.

19. Sterling R, Lim J, Frith L, Snowise NG, Jacques L, Haumann B. Efficacy and optimal dosing interval of the long-acting beta(2) agonist, vilanterol, in persistent asthma: a randomised trial. Respir Med. 2012;106(8):1110-1115.

20. Oliver AJ, Covar RA, Goldfrad CH, et al. Randomised trial of once-daily vilanterol in children with asthma on inhaled corticosteroid therapy. Respir Res. 2016;17:37.

21. Lötvall J, Bateman ED, Busse WW, et al. Comparison of vilanterol, a novel long-acting beta 2 agonist, with placebo and a salmeterol reference arm in asthma uncontrolled by inhaled corticosteroids. J Negat Results Biomed. 2014;13(1):9.

22. Chen X, Zheng X, Jiang J, et al. Pharmacodynamics and pharmacokinetics of fluticasone furoate/vilanterol in healthy Chinese subjects. Pharmacotherapy. 2015;35(6):586-599.

23. Nakahara N, Wakamatsu A, Kempsford R, et al. The safety, pharmacokinetics and pharmacodynamics of a combination of fluticasone furoate and vilanterol in healthy Japanese subjects. Int J Clin Pharmacol Ther. 2013; 51(8):660-671.

24. Kempsford R, Allen A, Bal J, Rubin D, Tombs L. The effect of ketoconazole on the pharmacokinetics and pharmacodynamics of inhaled fluticasone furoate and vilanterol trifenatate in healthy subjects. Br J Clin Pharmacol. 2013;75(6):1478-1487.

25. Allen A, Davis A, Hardes K, Tombs L, Kempsford R. Influence of renal and hepatic impairment on the pharmacokinetic and pharmacodynamic properties and tolerability of fluticasone furoate and vilanterol in combination. Clin Ther. 2012;34(12):2316-2332.

26. Oliver A, Bjermer L, Quinn D, et al. Modulation of allergen-induced bronchoconstriction by fluticasone furoate and vilanterol alone or in combination. Allergy. 2013;68(9):1136-1142.

27. Hughes SC, Shardlow PC, Hollis FJ, et al. Metabolism and disposition of fluticasone furoate, an enhanced-affinity glucocorticoid, in humans. Drug Metab Dispos. 2008;36(11):2337-2344.

28. Harrell AW, Siederer SK, Bal J, et al. Metabolism and disposition of vilanterol, a long-acting beta(2)-adrenoceptor agonist for inhalation use in humans. Drug Metab Dispos. 2013;41(1):89-100.

29. Bernstein DI, Bateman ED, Woodcock A, et al. Fluticasone furoate (FF)/ vilanterol $(100 / 25 \mathrm{mcg}$ or $200 / 25 \mathrm{mcg})$ or FF $(100 \mathrm{mcg})$ in persistent asthma. J Asthma. 2015;52(10):1073-1083.

30. Bleecker ER, Lotvall J, O'Byrne PM, et al. Fluticasone furoate-vilanterol 100-25 mcg compared with fluticasone furoate $100 \mathrm{mcg}$ in asthma: a randomized trial. J Allergy Clin Immunol Pract. 2014;2(5):553-561.
31. Bateman ED, O'Byrne PM, Busse WW, et al. Once-daily fluticasone furoate (FF)/vilanterol reduces risk of severe exacerbations in asthma versus FF alone. Thorax. 2014;69(4):312-319.

32. O'Byrne PM, Bleecker ER, Bateman ED, et al. Once-daily fluticasone furoate alone or combined with vilanterol in persistent asthma. Eur Respir J. 2014;43(3):773-782.

33. Oliver A, VanBuren S, Allen A, et al. Tolerability of fluticasone furoate/ vilanterol combination therapy in children aged 5 to 11 years with persistent asthma. Clin Ther. 2014;36(6):928e921-939e921.

34. Busse WW, O’Byrne PM, Bleecker ER, et al. Safety and tolerability of the novel inhaled corticosteroid fluticasone furoate in combination with the beta2 agonist vilanterol administered once daily for 52 weeks in patients $>=12$ years old with asthma: a randomised trial. Thorax. 2013;68(6):513-520.

35. Kempsford RD, Oliver A, Bal J, Tombs L, Quinn D. The efficacy of once-daily fluticasone furoate/vilanterol in asthma is comparable with morning or evening dosing. Respir Med. 2013;107(12): 1873-1880.

36. Woodcock A, Bleecker ER, Lotvall J, et al. Efficacy and safety of fluticasone furoate/vilanterol compared with fluticasone propionate/ salmeterol combination in adult and adolescent patients with persistent asthma: a randomized trial. Chest. 2013;144(4):1222-1229.

37. Lin J, Tang H, Chen P, et al. Efficacy and safety evaluation of oncedaily fluticasone furoate/vilanterol in Asian patients with asthma uncontrolled on a low- to mid-strength inhaled corticosteroid or lowdose inhaled corticosteroid/long-acting beta2-agonist. Allergy Asthma Proc. 2016;37(4):302-310.

38. Lin J, Kang J, Lee SH, et al. Fluticasone furoate/vilanterol 200/25 mcg in Asian asthma patients: a randomized trial. Respir Med. 2015;109(1): 44-53.

39. Dal Negro RW, Distante C, Bonadiman L, Turco P, Iannazzo S. Fluticasone furoate/vilanterol 92/22 mug once-a-day vs beclomethasone dipropionate/formoterol 100/6 mug b.i.d.: a 12-week cost analysis in mild-to-moderate asthma. Multidiscip Respir Med. 2016;11:20.

40. Hozawa S, Terada M, Haruta Y, Hozawa M. Comparison of early effects of budesonide/formoterol maintenance and reliever therapy with fluticasone furoate/vilanterol for asthma patients requiring step-up from inhaled corticosteroid monotherapy. Pulm Pharmacol Ther. 2016; 37:15-23.

41. Louie S, Zeki AA, Schivo M, et al. The asthma-chronic obstructive pulmonary disease overlap syndrome: pharmacotherapeutic considerations. Expert Rev Clin Pharmacol. 2013;6(2):197-219.

42. Ishiura Y, Fujimura M, Shiba Y, Ohkura N, Hara J, Kasahara K. A comparison of the efficacy of once-daily fluticasone furoate/vilanterol with twice-daily fluticasone propionate/salmeterol in asthma-COPD overlap syndrome. Pulm Pharmacol Ther. 2015;35:28-33.

43. Woodcock A, Bakerly ND, New JP, et al. The Salford Lung Study protocol: a pragmatic, randomised phase III real-world effectiveness trial in asthma. BMC Pulm Med. 2015;15:160.

44. Gross AS, Goldfrad C, Hozawa S, et al. Ethnic sensitivity assessment of fluticasone furoate/vilanterol in East Asian asthma patients from randomized double-blind multicentre phase IIb/III trials. BMC Pulm Med. 2015;15:165.

45. Rodrigo GJ, Plaza V. Once-daily fluticasone furoate and vilanterol for adolescents and adults with symptomatic asthma: a systematic review with meta-analysis. Ann Allergy Asthma Immunol. 2016;116(6): $565-570$.

46. Ingersoll KS, Cohen J. The impact of medication regimen factors on adherence to chronic treatment: a review of literature. J Behav Med.2008; 31(3):213-224.

47. Coleman CI, Limone B, Sobieraj DM, et al. Dosing frequency and medication adherence in chronic disease. J Manag Care Pharm. 2012;18(7): 527-539.

48. Lindsay JT, Heaney LG. Non-adherence in difficult asthma and advances in detection. Expert Rev Respir Med. 2013;7(6):607-614.

49. Fischer J, Wimmer A, Mahlich J. [Medication adherence in asthma therapy - a structured review]. Pneumologie. 2013;67(7):406-414. 
50. Lindsay JT, Heaney LG. Nonadherence in difficult asthma - facts, myths, and a time to act. Patient Prefer Adherence. 2013;7:329-336.

51. Bender B, Milgrom H, Rand C. Nonadherence in asthmatic patients: is there a solution to the problem? Ann Allergy Asthma Immunol. 1997;79(3):177-185; quiz185-176.

52. Bender B, Milgrom H, Apter A. Adherence intervention research: what have we learned and what do we do next? J Allergy Clin Immunol. 2003;112(3):489-494.

53. Feehan M, Ranker L, Durante R, et al. Adherence to controller asthma medications: 6-month prevalence across a US community pharmacy chain. J Clin Pharm Ther. Epub 2015 Aug 20.

54. McNally KA, Rohan J, Schluchter M, et al. Adherence to combined montelukast and fluticasone treatment in economically disadvantaged African American youth with asthma. J Asthma. 2009;46(9):921-927.

55. Shams MR, Fineman SM. Asthma adherence: how can we help our patients do it better? Ann Allergy Asthma Immunol. 2014; 112(1):9-12.

56. Heaney LG, Horne R. Non-adherence in difficult asthma: time to take it seriously. Thorax. 2012;67(3):268-270.

57. Komase Y, Asako A, Kobayashi A, Sharma R. Ease-of-use preference for the ELLIPTA(R) dry powder inhaler over a commonly used single-dose capsule dry powder inhaler by inhalation device-naive Japanese volunteers aged 40 years or older. Int J Chron Obstruct Pulmon Dis. 2014; 9:1365-1375.

58. Svedsater H, Dale P, Garrill K, Walker R, Woepse MW. Qualitative assessment of attributes and ease of use of the ELLIPTA dry powder inhaler for delivery of maintenance therapy for asthma and COPD. BMC Pulm Med. 2013;13:72.

59. Yun Kirby S, Zhu CQ, Kerwin EM, Stanford RH, Georges G. A preference study of two placebo dry powder inhalers in adults with COPD: ELLIPTA(R) dry powder inhaler (DPI) versus DISKUS(R) DPI. COPD. 2016;13(2):167-175.

60. Brealey N, Gupta A, Renaux J, Mehta R, Allen A, Henderson A. Pharmacokinetics of fluticasone furoate, umeclidinium, and vilanterol as a triple therapy in healthy volunteers. Int J Clin Pharmacol Ther. 2015; 53(9):753-764.

61. Bateman ED, Bleecker ER, Lotvall J, et al. Dose effect of once-daily fluticasone furoate in persistent asthma: a randomized trial. Respir Med.2012; 106(5):642-650

62. Lötvall J, Bleecker ER, Busse WW, et al. Efficacy and safety of fluticasone furoate 100 mug once-daily in patients with persistent asthma: a 24-week placebo and active-controlled randomised trial. Respir Med. 2014; 108(1):41-49.

63. Busse WW, Bateman ED, O'Byrne PM, et al. Once-daily fluticasone furoate $50 \mathrm{mcg}$ in mild-to-moderate asthma: a 24-week placebocontrolled randomized trial. Allergy. 2014;69(11):1522-1530.
64. O'Byrne PM, Woodcock A, Bleecker ER, et al. Efficacy and safety of once-daily fluticasone furoate $50 \mathrm{mcg}$ in adults with persistent asthma: a 12-week randomized trial. Respir Res. 2014;15:88.

65. Woodcock A, Bleecker ER, Busse WW, et al. Fluticasone furoate: once-daily evening treatment versus twice-daily treatment in moderate asthma. Respir Res. 2011;12:160.

66. Medley H, Orozco S, Allen A. Efficacy and safety profile of fluticasone furoate administered once daily in the morning or evening: a randomized, double-blind, double-dummy, placebo-controlled trial in adult and adolescent patients with persistent bronchial asthma. Clin Ther. 2012;34(8):1683-1695.

67. Busse WW, Bleecker ER, Bateman ED, et al. Fluticasone furoate demonstrates efficacy in patients with asthma symptomatic on medium doses of inhaled corticosteroid therapy: an 8-week, randomised, placebo-controlled trial. Thorax. 2012;67(1):35-41.

68. Bleecker ER, Bateman ED, Busse WW, et al. Once-daily fluticasone furoate is efficacious in patients with symptomatic asthma on low-dose inhaled corticosteroids. Ann Allergy Asthma Immunol. 2012;109(5): 353e354-358e 354.

69. van den Berge M, Luijk B, Bareille P, Dallow N, Postma DS, Lammers JW. Prolonged protection of the new inhaled corticosteroid fluticasone furoate against AMP hyperresponsiveness in patients with asthma. Allergy. 2010;65(12):1531-1535.

70. Allen A, Bal J, Cheesbrough A, Hamilton M, Kempsford R. Pharmacokinetics and pharmacodynamics of intravenous and inhaled fluticasone furoate in healthy Caucasian and East Asian subjects. Br J Clin Pharmacol. 2014;77(5):808-820.

71. Oliver A, VanBuren S, Allen A, et al. Safety, tolerability, pharmacokinetics, and pharmacodynamics of vilanterol, a novel inhaled long-acting beta-agonist, in children aged 5-11 years with persistent asthma: a randomized trial. Clin Pharmacol Drug Dev. 2014;3(3):215-221.

72. Allen RA, Wu W, Yao M, et al. Nerve regeneration and elastin formation within poly(glycerol sebacate)-based synthetic arterial grafts one-year post-implantation in a rat model. Biomaterials. 2014;35(1):165-173.

73. Calzetta L, Rinaldi B, Cazzola M, Matera MG. Pharmacodynamic and pharmacokinetic assessment of fluticasone furoate + vilanterol for the treatment of asthma. Expert Opin Drug Metab Toxicol. 2016; 12(7):813-822.

74. Allen A, Schenkenberger I, Trivedi R, et al. Inhaled fluticasone furoate/ vilanterol does not affect hypothalamic-pituitary-adrenal axis function in adolescent and adult asthma: randomised, double-blind, placebocontrolled study. Clin Respir J. 2013;7(4):397-406.

75. Oliver A, Quinn D, Goldfrad C, van Hecke B, Ayer J, Boyce M. Combined fluticasone furoate/vilanterol reduces decline in lung function following inhaled allergen $23 \mathrm{~h}$ after dosing in adult asthma: a randomised, controlled trial. Clin Transl Allergy. 2012;2(1):11.
Drug Design, Development and Therapy

\section{Publish your work in this journal}

Drug Design, Development and Therapy is an international, peerreviewed open-access journal that spans the spectrum of drug design and development through to clinical applications. Clinical outcomes, patient safety, and programs for the development and effective, safe, and sustained use of medicines are the features of the journal, which
Dovepress

has also been accepted for indexing on PubMed Central. The manuscript management system is completely online and includes a very quick and fair peer-review system, which is all easy to use. Visit http://www.dovepress.com/testimonials.php to read real quotes from published authors. 